International Journal of Agriculture, Environment and Bioresearch

Vol. 5, No. 02; 2020

ISSN: $2456-8643$

\title{
COMPARATIVE STUDIES OF DIFFERENT WEEDICIDES AGAINST WEEDS OF RICE CROP
}

\author{
Abdul Samad Soomro ${ }^{1^{*}}$ and Abdul Sattar Soomro ${ }^{2}$ \\ ${ }^{1}$ Integrated Pest Management Research Institute, Larkana Pakistan \\ ${ }^{2}$ Post Harvest Research Institute, Dokri Pakistan \\ https://doi.org/10.35410/IJAEB.2020.5490
}

\begin{abstract}
The experiment was conducted at Plant Physiology Department, Rice Research Institute, Dokri, Larkana Pakistan to evaluate the efficacy of weedicides against Rice crop weeds. Different sedges Cyprus rotundus, C, difformus, C, iria, F. milliacea and Scripus species. Grasses Echinochloa colona, E. Crus galli, Leptochloa chinensis and Paspalum distichu, broad leave weeds Sphenoclea zeylanica, Ipomoea aquatic, Ammannia coccinea and Nymphaea nouchhali were recorded in rice crop field. Results shown that the all the weedicides performed better than control (Un-treated). Weed population density was reduced significantly Sedges, grasses and broad leave weeds were controlled better by T-03 Pyranex Gold 60WDG followed by Refit 50\% EC, $(84 \%, 85 \%$ and 76.25 , and $80 \%, 77.50$ and $71.25 \%)$ respectively. Lowest control against all weeds were recorded (42.50\%) in T-07 Machete 60\%EC 800ml/Acre, while maximum weed control (81.3\%) was observed in T-03 Pyranex Gold 60WDG (100gms/Acre). Highest yield increase 2950kgs/A (131.11\%) was recorded in T-03 Pyranex Gold 60WDG followed by T-06 Refit 50\% EC, 2825kgs/A (125.55\%) compared with Control 2250kgs/A. Due to weed infestation, late maturity was observed in T-08 Control (97 days) while all treated plots were mature in 80 to 87 days after transplanting. Highest plant height $(104 \mathrm{~cm})$ was recorded in T-06 Refit 50\% followed by T-01 Sun Star Gold 60WP. Highest tiller per plant were observed 24 in T-03 Pyranex Gold 60WDG, while control recorded minimum number of tillers 18/P. Maximum yield was recorded 2950kg/A in T-03 Pyranex Gold 60WDG followed by T-06 Refit 50\%EC control yield was lowest $2250 \mathrm{kgs} / \mathrm{A}$ among all treatments.
\end{abstract}

Keywords: Rice, Weeds, weedicides, Control.

\section{INTRODUCTION}

Rice plays a significant role in the economy of Pakistan. It contributes $20 \%$ in foreign exchange earnings and is grown on an area of 2.57 million hectares with an average yield of 2075 $\mathrm{kg} /$ hectares (Anonymous 2006-07). The paddy yield of the country is either stagnant or declining day by day. It may be due to various factors but suboptimum plant population is of significant importance in transplanted rice (Mann and Ashraf 2001) These include problems of insect pests, diseases and weeds. (Imeokparia, and Okusanya1997; Akobundui. 1981). Weeds are the most frequent and widespread biotic constraint to productivity throughout the rice environments (Balasubramanian et al., 2007) Timing of weed emergence and the pressure exerted to the crop 
through interference are highly correlated so that resultant yield losses are usually higher when weeds emerge earlier or simultaneously with crop (Aldrich, 1987) There are several reasons for low productivity and the one due to weeds is the most important. Weeds compete with rice for moisture, nutrients, light, temperature and space. Uncontrolled weeds have caused yield reduction of 28 to 45\% in transplanted rice (Singh et al., 2007; Manhas et al., 2012). Butachlor, anilofos, oxadiargyl and pretilachlor are herbicides presently used for weed control in transplanted rice(Singh et al., 2004). Farmers are facing lot of weed troubles in their fields, Weeds emerging and its growth and development is faster than the crop, its impact clearly observed in yield of Rice Crop.

Weedicides are quick and fast acting source of weed control. Pre emergence and Post emergence Chemicals are often available in market for weed control. Evaluating their efficacy under field conditions for specific and better weed control was necessary. Keeping all above factors in mind current studies has been design to test the efficacy of Weedicides against Rice Crop weeds and its impact on Yield under filed conditions.

\section{MATERIALS AND METHODS}

The experiment was conducted at Plant Physiology Department, Rice Research Institute, Dokri, Larkana Pakistan in Kharif 18-19 for testing of different Weedicides and their impact on Rice Crop. The details of experiment are as under

\begin{tabular}{|l|l|l|l|}
\hline Details & $2018-19$ & No. of plants/row & 30 \\
\hline Year & RCBD & Plot Size & 32.4 Sq. meters \\
\hline Design & 03 & Nursery Sowing date & 07.06 .18 \\
\hline Replication & 08 & Transplanting date & 05.07 .18 \\
\hline Treatments & 27 & Variety & IR-6 \\
\hline No. of rows/entry & & & \\
\hline
\end{tabular}

Heavy infestation plot was selected; application was weedicides were made according to their recommended timings. Weeds infestation was recorded on weekly basis, weeds were recorded in 3 categories as sedges, grasses and broad leave weeds. Control of weedicides was measured in percentage. The detail of Treatment as under

\begin{tabular}{|l|l|l|l|l|}
\hline S\# & Brand Name & Formulations & Active & Dose/Acre \\
\hline 01 & Sun Star Gold & $60 \mathrm{WP}$ & Ethoxysulfuron & $20 \mathrm{gms}$ \\
\hline 02 & Bispyripac Sodium & $40 \mathrm{WP}$ & Bispyripac Sodium & $100 \mathrm{gms}$ \\
\hline 03 & Pyranex Gold & $60 \% \mathrm{WG}$ & Bensulfuron Methyl + Bispyribac sodium & $100 \mathrm{gms}$ \\
\hline
\end{tabular}


International Journal of Agriculture, Environment and Bioresearch

Vol. 5, No. 02; 2020

ISSN: $2456-8643$

\begin{tabular}{|l|l|l|l|l|}
\hline 04 & Melano Super & $60 \% \mathrm{WP}$ & Bensulfuron Methyl + Bispyribac Sodium & $100 \mathrm{gms}$ \\
\hline 05 & Top Star & $80 \% \mathrm{WP}$ & Oxadiargyl & $40 \mathrm{gms}$ \\
\hline 06 & Refit & $50 \% \mathrm{EC}$ & Pretilachlor & $500 \mathrm{ml}$ \\
\hline 07 & Machete & $60 \% \mathrm{EC}$ & Butachlor & $800 \mathrm{ml}$ \\
\hline 08 & Control & - & & - \\
\hline
\end{tabular}

Different agronomic studies 90\% Maturity, Plant Height in cms, Tillers/plant and yield from in each treatment were also recorded to evaluate the impact of Weedicides on growth and development and yield of rice crop.

\section{RESULTS AND DISCUSSION}

The experiment was conducted to evaluate the efficacy of weedicides against Rice crop weeds, different sedges were recorded such as Cyprus rotundus, C, difformus, C,iria, F. milliacea and Scripus species. The results shown that the Hieghtest sedges control was observed in T-03 Pyranex Gold 60WDG Cyprus rotundus, C, difformus, C,iria, F. milliacea and Scripus species $(80 \%, 85 \%, 85 \%, 90 \%$ and $80 \%)$ respectively while T-07 Machete $60 \% \mathrm{EC}$ was observed weaker against Sedges in conducted Experiment. See Graph 01.

Graph \#01 The Efficacy of different Weedicides against Sedges weeds in Percentage in Rice Crop.

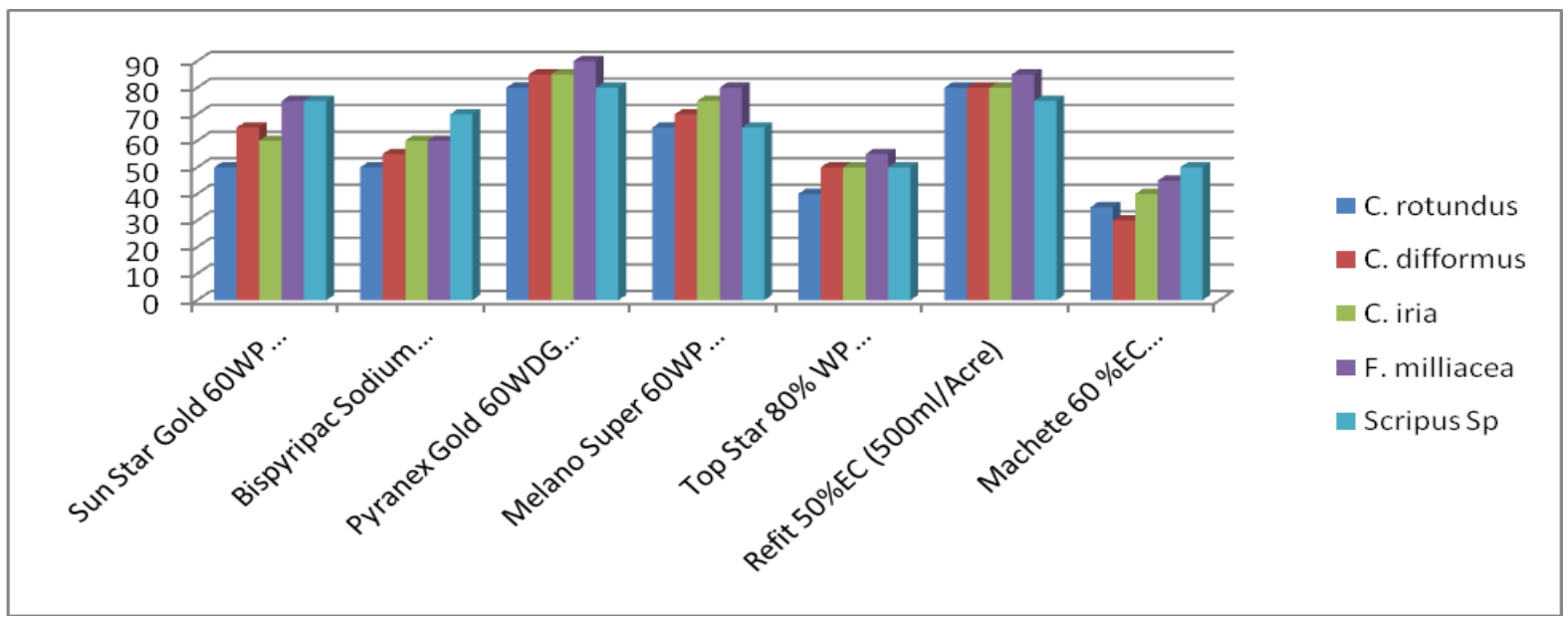

Grasses are often found in rice crop field specially Echinochloa colona and E. Crus galli. Both weeds population recorded highest in fields. T-03 Pyranex Gold 60WDG shown reduction of Echinochloa colona, E. Crus galli, Leptochloa chinensis and Paspalum distichum (85\%, 80\%, $85 \%$ and 90\%) respectively while T-05 Top Star 80\% WP was found be weaker against $E$. colona, and T-07 Machete $60 \%$ EC couldn't able to control E. Crus galli properly. See Graph \#02. 
Graph \#02 The Efficacy of different Weedicides against Grasses in Percentage in Rice Crop.

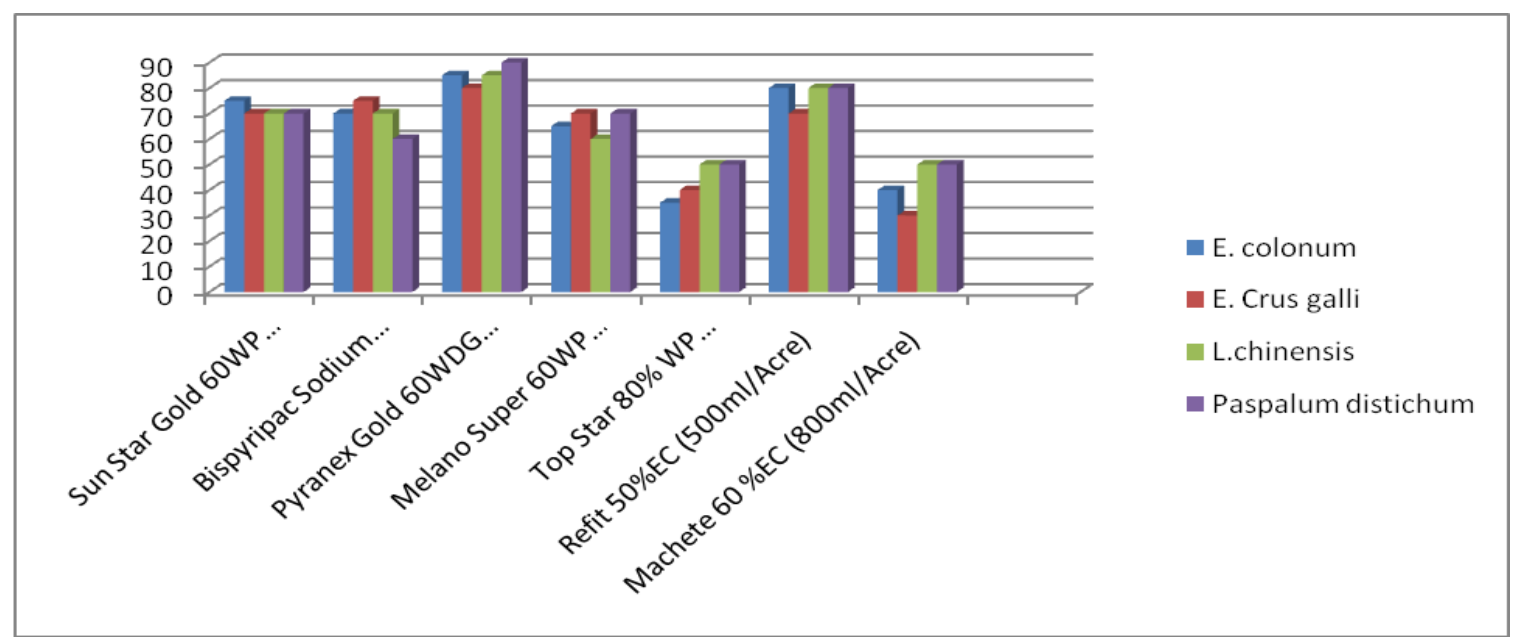

Different broad leave weeds were recorded such as Sphenoclea zeylanica Ipomoea aquatica Ammannia coccinea and Nymphaea nouchhali The results shown that the All the treatments reduced broad leave weeds T-03 Pyranex Gold shown over all better control against all weeds specially Sphenoclea zeylanica was better controlled up to 95\%, followed by Refit 50\%EC $90 \%$. while T-02 Bispyripac Sodium40WP, T-05 Top Star 80\% WP and T-07 Machete $60 \%$ EC was observed weaker against Ipomoea aquatica. See graph \#03

Graph \#03 The Efficacy of different Weedicides against broad leaves weeds in Percentage in Rice Crop.

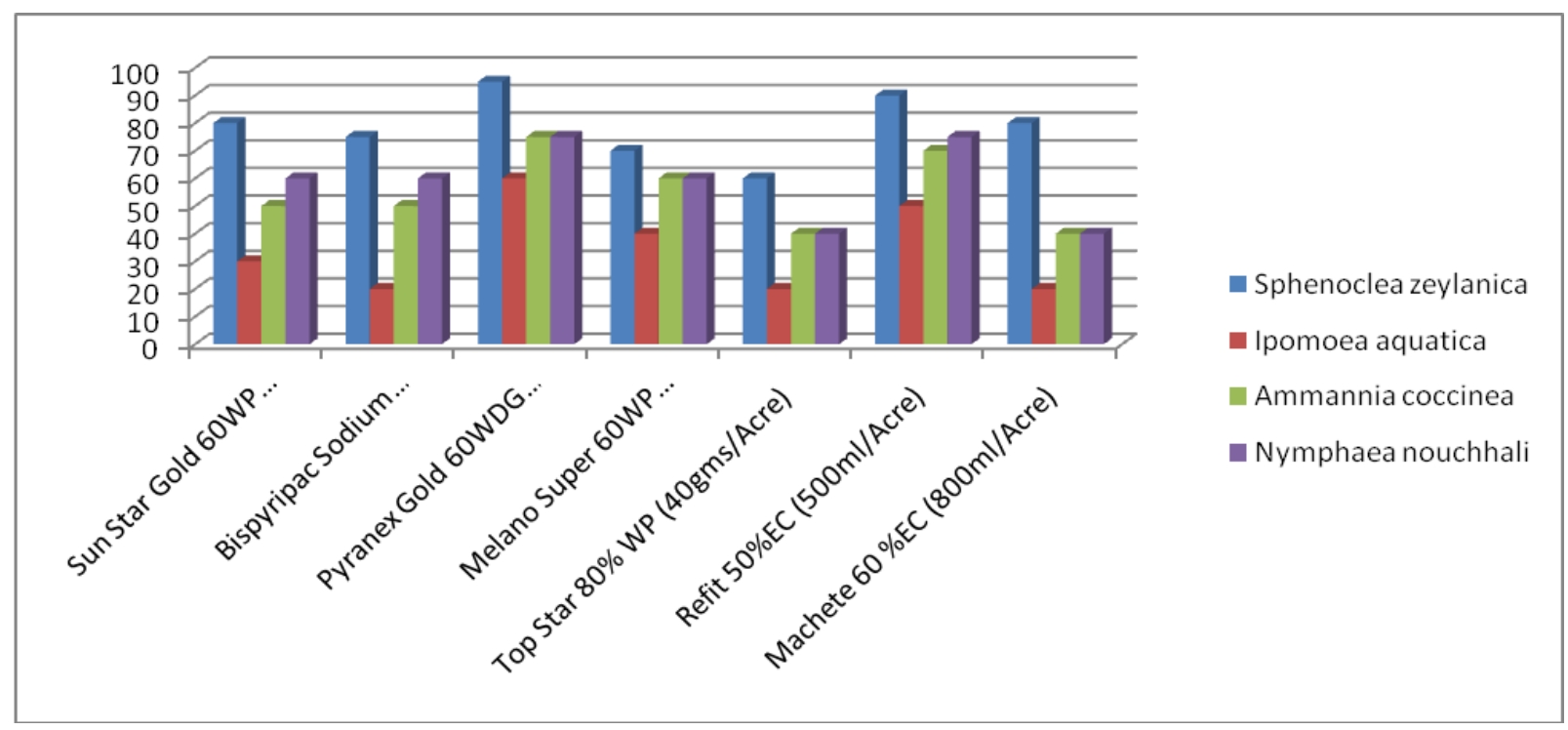


Table \# 01. Effect of different weedicides on weeds in Percentage.

\begin{tabular}{|l|l|l|l|l|l|}
\hline S.\# & Treatment & Sedges & Grasses & $\begin{array}{l}\text { B.Leave } \\
\text { weeds }\end{array}$ & $\begin{array}{l}\text { Total } \\
\text { Av }\end{array}$ \\
\hline $\mathbf{0 1}$ & Sun Star Gold 60WP (20gms/Acre) & 65 & 71.25 & 55 & 63.75 \\
\hline $\mathbf{0 2}$ & Bispyripac Sodium (100gms/Acre) & 59 & 68.75 & 51.25 & 59.66 \\
\hline $\mathbf{0 3}$ & Pyranex Gold 60WDG (100gms/Acre) & 84 & 85 & 76.25 & 81.75 \\
\hline $\mathbf{0 4}$ & Melano Super 60WP (100gms/Acre) & 71 & 66.25 & 57.5 & 64.92 \\
\hline $\mathbf{0 5}$ & Top Star 80\% WP (40gms/Acre) & 49 & 43.75 & 40 & 44.25 \\
\hline $\mathbf{0 6}$ & Refit 50\%EC (500ml/Acre) & 80 & 77.5 & 71.25 & 76.25 \\
\hline $\mathbf{0 7}$ & Machete 60\%EC (800ml/Acre) & 40 & 42.5 & 45 & 42.50 \\
\hline $\mathbf{0 8}$ & Control & - & - & - & - \\
\hline
\end{tabular}

The impact of Weedicides was observed against rice crop growth and development. The results shown that due to weed infestation, late maturity was observed in T-08 Control While all treated plots were mature to 80 to 87 days after transplanting. Hightest plant height $(104 \mathrm{~cm})$ was recorded in T-06 Refit 50\%EC followed by T-01 Sun Star Gold 60WP. Height tiller per plant were observed in 24 in T-03 Pyranex Gold 60WDG, followed by T-6 Refit 50\%EC while control recorded minimum number of tillers $18 / \mathrm{P}$. Maximum yield was recorded $2950 \mathrm{~kg} / \mathrm{A}$ in T-03 Pyranex Gold 60WDG followed by T-06 Refit 50\%EC, while control yield was recorded lowest $2250 \mathrm{kgs} / \mathrm{A}$ among all treatments. See table \#02

Table \# 02. Effect of different Weedicides on different development stages and Yield of Rice Crop under field conditions.

\begin{tabular}{|c|c|c|c|c|c|c|}
\hline S.\# & Treatment & $\begin{array}{l}90 \% \\
\text { Maturity } \\
\text { Days }\end{array}$ & $\begin{array}{l}\text { Plant } \\
\text { Height } \\
(\mathrm{Cm})\end{array}$ & $\begin{array}{l}\text { Tillers } \\
\text { / } \\
\text { Plant }\end{array}$ & $\begin{array}{l}\text { Yield } \\
\text { Kgs/Acre }\end{array}$ & $\begin{array}{l}\text { Yield } \\
\text { Increase } \\
\%\end{array}$ \\
\hline 01 & Sun Star Gold 60WP (20gms/Acre) & 85 & 103 & 21 & 2633 & 117.0 \\
\hline 02 & Bispyripac Sodium (100gms/Acre) & 90 & 98 & 18 & 2542 & 112.9 \\
\hline 03 & $\begin{array}{l}\begin{array}{l}\text { Pyranex } \\
(100 \mathrm{gms} / \text { Acre })\end{array} \\
\text { Gold }\end{array}$ & 88 & 101 & 24 & 2950 & 131.11 \\
\hline
\end{tabular}


International Journal of Agriculture, Environment and Bioresearch

Vol. 5, No. 02; 2020

ISSN: $2456-8643$

\begin{tabular}{|l|l|l|l|l|l|l|}
\hline $\mathbf{0 4}$ & Melano Super 60WP (100gms/Acre) & 87 & 100 & 20 & 2811 & 124.93 \\
\hline $\mathbf{0 5}$ & Top Star 80\% WP (40gms/Acre) & 80 & 101 & 20 & 2619 & 116.4 \\
\hline $\mathbf{0 6}$ & Refit 50\%EC (500ml/Acre) & 85 & 104 & 22 & 2825 & 125.55 \\
\hline $\mathbf{0 7}$ & Machete 60\%EC (800ml/Acre) & 80 & 102 & 21 & 2352 & 104.53 \\
\hline $\mathbf{0 8}$ & Control & 97 & 96 & 18 & 2250 & - \\
\hline
\end{tabular}

Overall results shown that the all the weedicides performed better than control (Un-treated) Weed population density was reduced significantly Sedges, grasses and broad leave weeds were controlled better by T-03 Pyranex Gold 60WDG followed by Refit 50\% EC, (84\%, 85\% and 76.25 , and $80 \%, 77.50$ and $71.25 \%$ ) respectively. Overall Lowest control against all weeds were recorded (42.50) in T-07 Machete 60\% EC (800ml/Acre) while maximum control(81.3) was observed in T-03 Pyranex Gold 60WDG (100gms/Acre) followed by T-06 Refit 50\%EC (500ml/Acre). Highest yield increase 2950kgs/A (131.11\%) was recorded in T-03 Pyranex Gold (Bensulfuron Methyl + Bispyribac Sodium) 60WDG followed by T-06 Refit 50\% EC (), $2825 \mathrm{kgs} / \mathrm{A}$ (125.55\%) compared with Control 2250kgs/A (See Table 03). Hussain et al (2008) tested four weedicides compared their efficacy with hand weeding. Among the weedicides Nominee 100SC (bispyribac sodium) and Sunstar Gold 60WG (Ethoxy sulfuron) proved as the best weedicides with 90.5 and $87.19 \%$ weed control respectively. The paddy yield in both the weedicide treatments was also comparatively higher than other weedicides. The highest net benefit was obtained by the application of nominee 100sc. Mahajan et al (2009) weed density and dry weight were negatively correlated with rice grain yield Post-emergence application of bispyribac Na $25 \mathrm{~g} / \mathrm{ha}$ and penoxsulam $25 \mathrm{~g} / \mathrm{ha}$ could effectively control all the weeds. Samar Singh et al (2006) pretilachlor with safener $\left(500 \mathrm{~g}\right.$ a.i. ha $\left.{ }^{-1}\right)$ as pre-emergence applications followed by one hand-weeding were effective in controlling weeds, increasing grain yield. Prakash el al (2012) of Bispyribac Sodium SC@ $50 \mathrm{~g}$ a.i/ha at 15-20 DAT produced significantly higher grain yield (56.99q/ha which was at par with Bispyribac Sodium SC@ $35 \mathrm{~g}$ a.i/ha at 15-20 DAT. Number of weeds and dry weight of weeds also minimum in these treatments

\section{REFERENCES}

Anonymous (2006-07). Economic Survey of Pakistan. Govt. of Pakistan. Finance Division Economic Advisory Wing Islamabad.

Akobundui, O. 1981. Weed Control in direct-seeded lowland rice under poor water control conditions. Weed Research 21:273-278.

Aldrich, R. J. (1987). Predicting crop yield reduction from weeds. Weed Technol. 1(3): 199-206.

Balasubramanian, V., Sie, M., Hijmans, R.J. and Otsuka, K. (2007) Increasing rice production in subSaharan Africa: challenges and opportunities. Advances in Agronomy 94, 55-133. 
Vol. 5, No. 02; 2020

ISSN: $2456-8643$

Hussain S., M. Ramzan, M. Akhter and M. Aslam (2008) WEED MANAGEMENT IN DIRECT SEEDED RICE J. Anim. Pl. Sci. 18 (2-3)

Imeokparia, P. O., Okusanya, B. A. 1997. Relative effectiveness and Economics of Cultural and Chemical Control Methods in Lowland Rice (Oriza sativa) in the Southern Guinea Savanna of Nigeria. Nigeria Journal of Weed Science, 10, pp.35-47.

Mann, R. A. and M. Ashraf (2001). Improvement of Basmati and its production practices in Pakistan. pp: 129-148. In: Specialty Rices of the world: Breeding, production and Marketing. Edited by R. C. Chaudhary; D. V. Tran and R. Duffy. Food and Agricultural Organization of the United Nations, Rome.

Mahajan G. , B. S. Chauhan \& D. E. Johnson (2009) Weed Management in Aerobic Rice in Northwestern Indo-Gangetic Plains. Journal of Crop Improvement 23 (4)

Manhas SS, Govindra Singh, Dharam Singh, Khajuria V., (2012). Effect of tank-mixed herbicides on weeds and transplanted rice (Oryza sativa L.). Ann. Agric. Res. New Series $33(1-2): 25-31$

Prakash Chandra, Shivran R.K., Koli N.R. (2011) Bio efficacy of new herbicides on weed dynamics, yield attributes, yield and weed control efficiency in transplanted rice Biosciences:4,2: (224-227)

Samar Singh, J.K. Ladha', R.K. Gupta, Lav Bhushan, A.N. Rao, B. Sivaprasad, P.P. Singh (2006) Evaluation of mulching, intercropping with Sesbania and herbicide use for weed management in dry-seeded rice (Oryzas sativa ) http://doi.org/10.1016/j.cropro.2006.04.024

Singh G, Singh VP, Singh M (2004). Effect of almix and butachlor alone and in combinations on transplanted rice and associated weeds. Indian J. Weed Sci. 36(1-2):64-67.

Singh P, Singh R, Singh KN (2007). Efficacy of new herbicides in transplanted rice under temperate conditions of Kashmir. Indian J. Weed Sci. 39(3-4):167-171 